\title{
Male Cone Evolution in Conifers: Not All That Simple
}

\author{
Christian Schulz¹, Kristina Vanessa Klaus1, Patrick Knopf', Marcus Mundry³, \\ Veit Dörken', Thomas Stützel1 \\ ${ }^{1}$ Evolution and Biodiversity of Plants, Ruhr-Universität Bochum, Bochum, Germany \\ ${ }^{2}$ Botanischer Garten Rombergpark, Dortmund, Germany \\ ${ }^{3}$ Heisenberg Gymnasium, Dortmund, Germany \\ ${ }^{4}$ Fachbereich Biologie M 613, Universität Konstanz, Konstanz, Germany \\ Email: Christian.Schulz-3@rub.de
}

Received 10 June 2014; revised 24 July 2014; accepted 26 August 2014

Copyright (C) 2014 by authors and Scientific Research Publishing Inc.

This work is licensed under the Creative Commons Attribution International License (CC BY).

http://creativecommons.org/licenses/by/4.0/

c) (7) Open Access

\begin{abstract}
Despite the simple structure of male conifer cones, there is an enormous variability in cone properties observed upon more careful examination. The diversity ranges from simple cones to compound cones. Moreover, cones can be distinguished according to different spatial distributions on the tree. Simple cones are distributed either as solitary cones or as fascicular or clustered aggregations, while compound cones only exhibit fascicular or clustered aggregations. Here, we demonstrate that these different spatial distribution patterns correlate with distinct leaf types and variable branching frequencies. Furthermore, we provide new insights into the evolution of the sporangiophore, particularly in Taxaceae. Two notably important and fast-evolving characters of conifers are the number of sporangia per sporangiophore and the number of sporangiophores per cone. We demonstrate, across many species and types of cones, how these characters are able to adjust according to the optimal amount of pollen.
\end{abstract}

\section{Keywords}

Pollen Cone, Phylogeny, Gymnosperms, Compound Cone, Microsporophyll

\section{Introduction}

Recent conifers consist of 6 families [1], 66 - 70 genera [2]-[5], and 615 species [3]. The systematics of conifers has undergone several changes; however, most recent publications show that the 6 conifer families are monophyletic. The Pinaceae with 11 genera [3] is the most basal conifer family and sister to all other conifers. Araucari- 
aceae with 3 genera [3] and Podocarpaceae with 18 - 19 genera [3] [4] [6] are sister groups and together they comprise a sister group of the clade containing the Cupressaceae, Sciadopityaceae, and Taxaceae families. Cupressaceae with 27 - 30 genera [2] [3] [5] and Taxaceae with 6 genera [3] (including Cephalotaxaceae) are sister groups, which together form the sister group of the monotypic family Sciadopityaceae (Sciadopitys verticillata) [1].

Fossils of male conifer cones have been found throughout the world, the oldest of which date to the Jurassic Period [7]-[9]. The morphology of the male cone (i.e. the pollen cone or microstrobilus) within conifers has typically been described as uniform, simple, and terminal. Male cones consist of a central axis with several sporangiophores (microsporophylls), each with one or multiple microsporangia releasing pollen at maturity. Male cones never get woody, they are not persistent, and their growth is limited [3]. Male cone size varies greatly from $2 \mathrm{~mm}$ in Juniperus communis up to $24 \mathrm{~cm}$ in Araucaria rulei [10]. Morphological descriptions of male cones are frequently adopted from earlier publications, and there are a very limited number of recent publications examining the variability of conifer morphological characteristics and their modifications [11] [12]. In contrast, there has been more investigation of female cone properties [13]-[15]. However, the existing studies of male conifer cones are controversial, as they are open to a number of interpretations and pose many remaining questions.

The male cone was considered in early work to be a flower analogue [16], as described in Chamaecyparis [11]. Parlatore [17] equated one sporangiophore with a single flower, e.g. in the genus Pseudotaxus [12]. The genus Cephalotaxus possesses compound cones (inflorescences) in the same position, where Torreya instead has simple male cones [18]. Furthermore, the male cones of Pseudotaxus differ from simple male cones of other species in having additional pherophylls (subtending leaves), which indicates that the cone has to be considered as a strongly reduced inflorescence [12]. In consideration of the close relationship of these two genera and the position of their male cones in the branching system, the Pseudotaxus (compound) male cone is likely to be a reduction of the Cephalotaxus compound male cone type [12]. The transition series of male reproductive structures in Taxaceae is well investigated and illustrated in [18] and [12]. However, no reported studies have investigated how this hypothetical series fits into the current phylogeny, which would be best tested using recent methods of trait reconstruction. Furthermore, in several conifer genera (e.g., in the genera Cryptomeria, Cunninghamia, and Podocarpus), the male cones form aggregations on branches [3]. These aggregations vary widely in composition and shape, and it remains unknown which systems possess morphological features of a compound cone (inflorescence) and which are instead just aggregations of simple male cones.

Male cones of conifers consist of several sporangiophores, each containing from one to many sporangia. As the number of sporangia may vary between one and five even within one species (Juniperus phoenicea), it appears logical to then treat sporangiophores and male cones as homologous structures throughout conifers [19][21]. Almost all conifers have sporangiophores with sporangia only on the abaxial side, a characteristic termed hyposporangiate. With few exceptions, Taxaceae alone have sporangiophores with sporangia surrounding a central stalk, which is referred to as perisporangiate [12] [18]. The perisporangiate character is proposed to be a primitive form by some researchers [22] [23]. It seems, however, that these conclusions were reached through a kind of out-group comparison, even though this term was not used and the authors also did not state their arguments clearly. The occurrence of perisporangiate sporangiophores basal to seed plants in Equisetum, as well as the consideration that Taxaceae (excluding Cephalotaxaceae) are a sister group of all other conifers, might have led to this interpretation. However, molecular data have shown that ferns are sister to seed plants [24] and Taxaceae are nested within conifers [1]. The presumed implicit argument is thus today explicitly wrong.

A sporangiophore consists of a stalk and a scutellum (plane structure). This plane-like structure can be peltate, as in many Cupressaceae s. str. [11] or phyllome-like, as in Cephalotaxus [18]. Most studies consider sporangiophores to be microsporophylls or at least refer to them as microsporophylls. The term sporophyll implies there is homology to a leaf, a hypothesis, which is still controversial.

Conifers release an enormous amount of anemophilous pollen, as demonstrated in Cupressus sempervirens, which is distributed throughout European and North-African Mediterranean countries [25]. This high amount of pollen is important to ensure successful pollination. Four important features determine the amount of pollen a tree can produce: the number of male cones on the tree, the number of sporangiophores per cone, the number of sporangia per sporangiophore, and the number of pollen per sporangium. There are no studies of these features across all conifers. Though individual examples can be found in several studies [3] [14] [26], there is still an enormous lack of knowledge on this topic.

In summary, the evolutionary characters of the male conifer cones have often been investigated only within a 
few species or genera. The results and conclusions of these studies have led to generalized interpretations based on work done in other genera and outdated publications. The aim of this study was to comprehensively investigate the important characters of male cones in all extant conifer genera in the context of phylogenetics and to thus derive an accurate overview about character evolution in conifers. We further aim to improve the understanding of conifer biology in terms of the evolution of sporangiophores, the number of sporangiophores, sporangia, the number of sporangia, and leaves. The character trait reconstruction we present was obtained using the most recent phylogeny and should lead to a better and more complete understanding of the direction of evolution and character origin in conifers.

\section{Material and Methods}

\subsection{Taxon Sampling}

Plant material of several individuals and species of all extant conifer genera was obtained from the living collections of several international botanical gardens (BG) (Atlanta BG, Australian National BG, BG Bayreuth, Pinetum Blijdenstein, Belgium National BG, BG Bochum, BG Bonn, BG Darmstadt, BG Düsseldorf, Royal BG Edinburgh, Arboretum Ellertrop, Palmengarten Frankfurt, Gondwana Nursery Vallejo, Arboretum Günterstal, BG Kew, BG Marburg, Montgomery Botanical Center, BG Münster, New York BG, Ottway Ridge Arboretum, Botanicka Zahrada Praha, BG of the Smith College) and from several herbaria (BOCH, K, L, NY, P). Our analysis focused on the number of sporangiophores per cone, the number of sporangia per sporangiophore, sporangiophore type (perisporangiate, hyposporangiate), leaf type (scale, needle leaves), and spatial arrangement of male cones (solitary, fascicular, clustered).

\subsection{Morphological Methods}

Photos of male cones were taken using a Nikon Coolpix 995 or a Keyence VHX-500F. Fertile branchlets with male cones were dissected under a stereomicroscope, fixed in FAA (a formula of formalin, acetic acid, $70 \%$ ethanol; at 5:5:90 ratio), and subsequently stored in 70\% ethanol. Cone diagrams were drawn using CorelDraw (Corel).

For investigations by light microscopy, longitudinal sections of male cones were made using the classical paraffin technique and safranin-astrablue staining [27]. The sections were studied using an Axioplan (Zeiss) light-microscope applying using the bright field technique. To document our results, photomicrographs were obtained using an Olympus ColourView II camera and Analysis software v. 3.2 (Olympus).

For the scanning electron microscopy (SEM) studies, fixed plant material was dehydrated in FDA (formaldehyde dimethyl acetal) for at least 24 h [28] and dried using the Critical Point Dryer CPD030 (Balzers). The dried specimens were fixed on aluminum stubs, coated using the Sputter Coater SCD 50 Bal-tec (Balzers), and examined with a DSM 950 SEM (Zeiss). The results were documented and analyzed using Digital Image Processing Software 2.2 (DIPS-Leipzig).

\subsection{Phylogenetic Analyses}

Sequences for the phylogenetic analysis were taken from the GENBANK database (National Center for Biotechnology Information, NCBI). The matrix used for the phylogenetic reconstruction was a concatenated sequence dataset containing four phylogenetic markers: 18S (51 taxa), rbcL (68 taxa), matK (69 taxa), and phyP (62 taxa). The concatenated sequence matrix contained 67 conifer taxa, representing every extant conifer genus (Xanthocyparis and Callitropsis was included in Cupressus; Sundacarpus was included in Prumnopitys) and 2 other gymnosperm taxa as a phylogenetic out-group. Sequence editing for the four independent matrixes was performed using the program Bioedit version 7.1.3.0 [29]. For the sequence concatenation we used the program SequenceMatrix version 1.7.8 [30]. Multiple sequence alignment was performed using MUSCLE 3.8.31 [31] with default parameters. The concatenated matrix consisted of 9427 unambiguously aligned positions. The bestfitting DNA substitution model for the concatenated matrix was determined using MrModeltest [32]. The general time reversible model of evolution with a parameter for invariant sites and rate heterogeneity modeled under a gamma distribution (GTR + I + G) was determined as the best fitting model. The phylogenetic reconstruction using Bayesian inference was performed with the MrBayes 3.1.2 program [33]. We ran the analysis for 20 million generations, sampling trees every 1000 generations. 25\% of the trees from both independent Bayesian 
MCMC runs were removed as burn-in.

\subsection{Character Evolution}

We used the Parsimony Ancestral States reconstruction implemented in Mesquite for discrete characters [34]. Ancestral character states reconstructions of continuous characters were performed using the APE [35] and phytool package [36] implemented in $\mathrm{R}$ version 3.0.1 [37]. The 50\% majority consensus tree resulting from the Bayesian analyses was used as the basic tree for the reconstructions.

\section{Results}

\subsection{Male Cone Distribution}

Cone distribution can be categorized according to three distinct types of spatial distribution of male cones on the branch: solitary and fascicular or clustered aggregations (Figure 1, Figure 2, Table 1). 30 genera show terminal solitary male cones, 25 genera show axillary fascicular male cones, 10 genera show male cones in clusters, and 2 genera (Juniperus, Athrotaxis) show male cones of different types.

1) Solitary type-Male cones of most conifer genera are solitary and terminal (i.e. at the end of a normal vegetative ultimate branchlet), as in Actinostrobus (Figure 1(a3)). Sometimes the terminal branchlet branches once or twice before forming a male cone, such that the branchlet develops 2 or 3 terminal male cones in close proximity, as in Callitris (Figure 1(b5)). Most male cones are distributed regularly across larger branches (Figure 1(b2), Figure 1(c1)). In many genera, only certain branches of the tree form male cones at pollination time, while other branches stay vegetative. The tree does not form the male cones on the same branches every year. Shortly before pollination, the internodes between the sporangiophores grow intercalary to provide the necessary space for optimal pollen release. The strands probably tear off due to this elongation, which promotes the drying out and thus opening of the sporangia and the subsequent release of pollen. After pollination, the male cones drop off and the branchlets then lose the ability to continue terminal growth. Because of this, male cones cannot proliferate in contrast to female cones. Genera with solitary male cones usually show scale leaves (Figure 1(a3), Figure 1(b3), Figure 1(c1), Figure 1(c5)).

2) Fascicular type-Fascicular type male cones are axillary (in an axil of a pherophyll), not terminal, as in Cryptomeria. Several male cones develop in the axils of consecutive pherophylls (leaves), meaning that several male cones are observed close together (Figure $\mathbf{1}(\mathbf{d} \mathbf{1})$ ). As the male cones are only axillary, the branchlet can continue growing terminally. Therefore, this structure has to be termed as an aggregation of male cones and not as a compound male cone. Thus, the development of the male cones is sequential. Usually, a fertile branch carries several axillary male cones (e.g. Afrocarpus falcatus, Figure 1(a4)), but in some cases only a single axillary (but, importantly not terminal) male cone develops. The axillary male cones may be simple male cones (e.g. in Cryptomeria, Figure 1(d1)) or compound male cones (e.g. in Cephalotaxus, Figure 1(c4), Figure 3(a)). Genera with fascicular male cones usually have needle or acicular leaves though there are exceptions. For example, in Agathis, plane leaves are observed (Figure 1(a5)) and in Phyllocladus, phylloclades are observed (Figure 2(b4)).

3) Clustered type-In clustered male cones, the shape of the leaves varies between the vegetative and the generative parts of the branch. The leaves are smaller, thinner, and more scale-like in the generative parts. Scalelike leaves (bud scales or cataphylls) can be followed by a cluster of male cones, as in Cunninghamia (Figure $\mathbf{1}(\mathbf{d} 2)$ ). The development of the male cones is therefore simultaneous. In some genera, such as Cunninghamia, these clusters may proliferate (Figure 1(d2), Figure 4(1)). Genera with clustered male cones usually have needle or acicular leaves like Acmopyle (Figure 1(a2)). An exception is the genus Nageia, which has broader leaves (Figure 2(a5)).

\subsection{Leaves and Branching Pattern}

40 genera of conifers have needle leaves, whereas 24 genera show scale leaves. In three genera (Athrotaxis, Halocarpus, and Juniperus) both needle and scale leaves occur. Our analysis shows that a $30 \mathrm{~cm}$ branch of Chamaecyparis with scale leaves has about 900 terminal ends resulting from 900(-1) branching processes (Figure 4(k)). However, a $30 \mathrm{~cm}$ branch of Cunninghamia with needle leaves has two terminal ends resulting from a single branching process (Figure $4(j)$ ). In other genera similar tendencies are observed; taxa with scale 

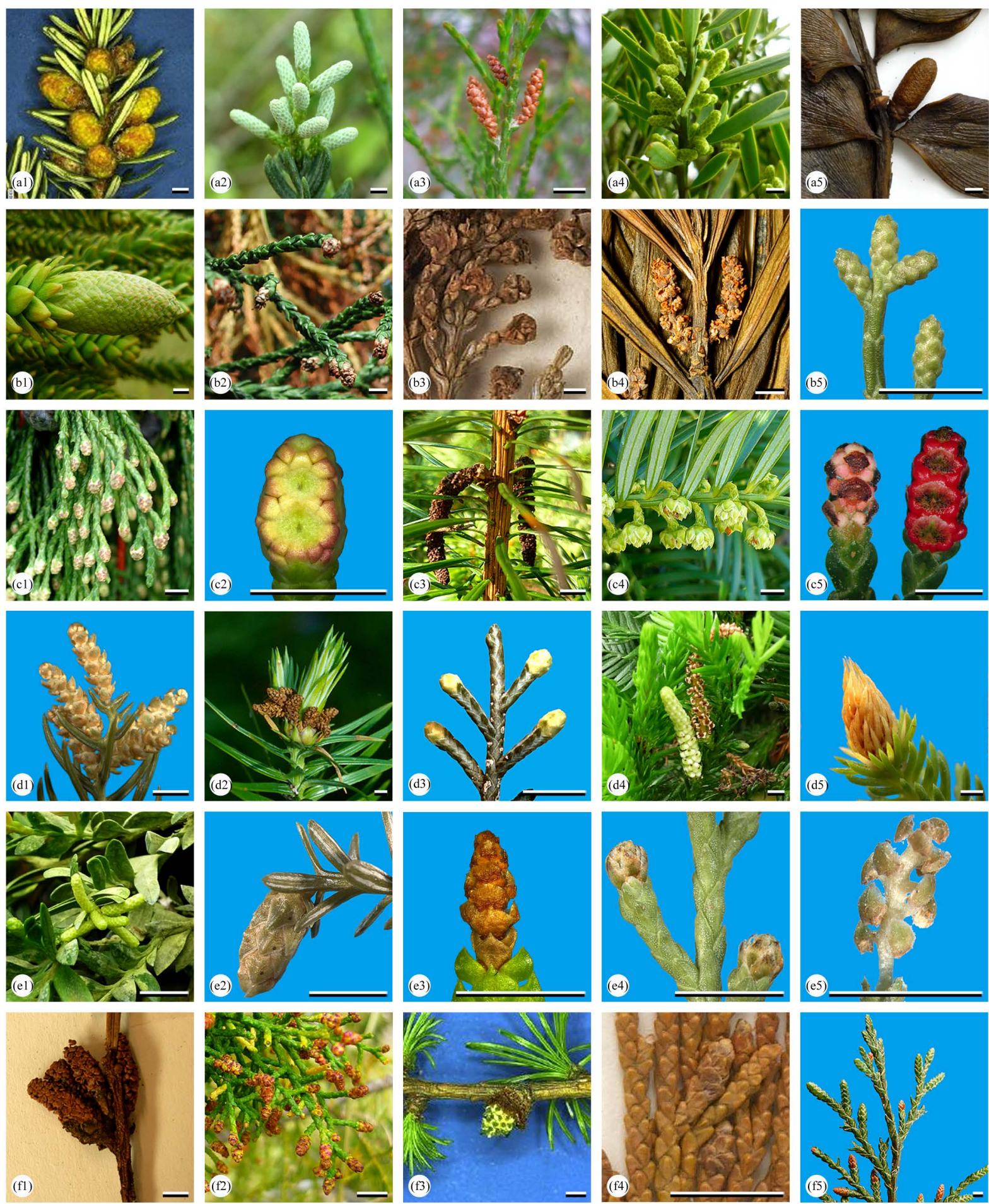

Figure 1. Male cones of conifers. (a1) Abies koreana; (a2) Acmopyle pancheri; (a3) Actinostrobus pyramidalis; (a4) Afrocarpus falcatus; (a5) Agathis spathulata; (b1) Araucaria laubenfelsii; (b2) Athrotaxis laxifolia; (b3) Austrocedrus chilensis; (b4) Austrotaxus spicata; (b5) Callitris preissii; (c1) Callitropsis nootkatensis; (c2) Calocedrus decurrens; (c3) Cathaya argyrophylla; (c4) Cephalotaxus sinensis; (c5) Chamaecyparis obtusa var. obtusa (left) \& Chamaecyparis lawsoniana (right); (d1) Cryptomeria japonica; (d2) Cunninghamia lanceolata; (d3) Cupressus arizonica var. glabra; (d4) Dacrycarpus kinabaluensis; (d5) Dacrydium × suprinii; (e1) Falcatifolium taxoides; (e2) Fitzroya cupressoides; (e3) Fokienia hodginsii; (e4) Glyptostrobus pensilis; (e5) Juniperus ashei; (f1) Keteleeria fortunei; (f2) Lagarostrobos franklinii; (f3) Larix decidua; (f4) Lepidothamnus fonkii; (f5) Libocedrus bidwillii. Scale $=5 \mathrm{~mm}$. 

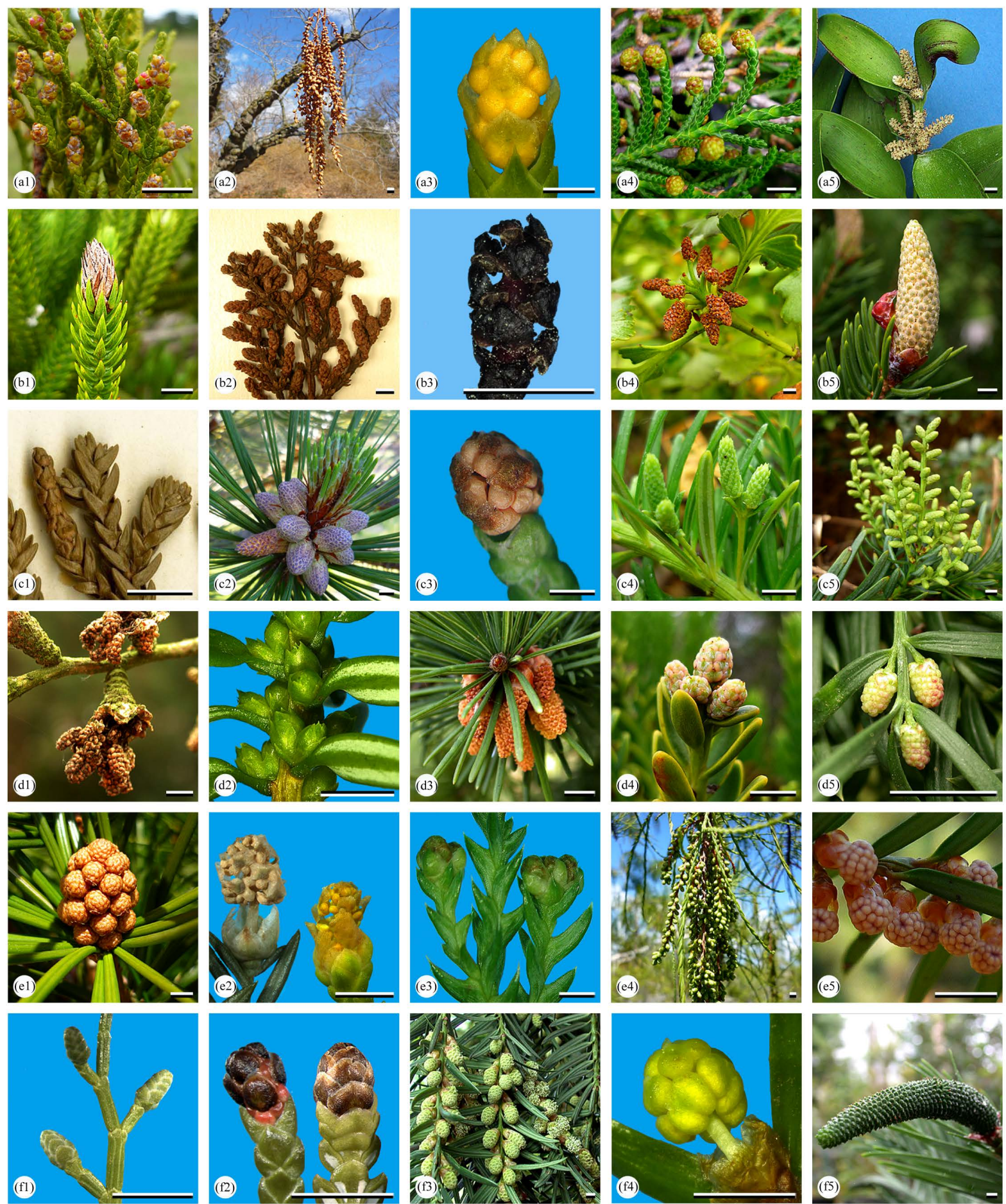

Figure 2. Male cones of conifers. (a1) Manoao colensoi; (a2) Metasequoia glyptostroboides; (a3) Microbiota decussata; (a4) Microcachrys tetragona; (a5) Nageia nagi; (b1) Neocallitropsis pancheri; (b2) Papuacedrus papuana var. papuana; (b3) Parasitaxus usta; (b4) Phyllocladus trichomanoides var. trichomanoides; (b5) Picea torano; (c1) Pilgerodendron uviferum; (c2) Pinus radiata; (c3) Platycladus orientalis; (c4) Podocarpus gnidioides; (c5) Prumnopitys andina; (d1) Pseudolarix amabilis; (d2) Pseudotaxus chienii; (d3) Pseudotsuga menziesii; (d4) Retrophyllum minus; (d5) Saxegothaea conspicua; (e1) Sciadopitys verticillata; (e2) Sequoia sempervirens (left) \& Sequoiadendron giganteum (right); (e3) Taiwania cryptomerioides; (e4) Taxodium distichum var. imbricatum; (e5) Taxus floridana; (f1) Tetraclinis articulata; (f2) Thuja plicata (left) \& Thujopsis dolabrata var. dolabrata (right); (f3) Torreya californica; (f4) Tsuga canadensis; (f5) Wollemia nobilis. Scale $=5 \mathrm{~mm}$ (scales in (a3) \& (c3) = $1 \mathrm{~mm})$. 
Table 1. Character and character states of the conifer genera.

\begin{tabular}{|c|c|c|c|c|c|c|}
\hline Genus & $\begin{array}{c}\text { Spartial } \\
\text { distribution }\end{array}$ & Cone type & $\begin{array}{c}\text { Sporangiophore } \\
\text { type }\end{array}$ & $\begin{array}{c}\text { Number of } \\
\text { sporangiophores }\end{array}$ & $\begin{array}{l}\text { Number of } \\
\text { sporangia }^{*}\end{array}$ & Leaf type \\
\hline Abies & $\mathrm{f}$ & si & $\mathrm{h}$ & $50-105$ & 2 & $\mathrm{n}$ \\
\hline Acmopyle & c & si & $\mathrm{h}$ & $60-90$ & 2 & $\mathrm{n}$ \\
\hline Actinostrobus & $\mathrm{s}$ & si & h & $10-27$ & $2-4$ & sc \\
\hline Afrocarpus & $\mathrm{f}$ & si & $\mathrm{h}$ & $40-60$ & 2 & $\mathrm{n}$ \\
\hline Agathis & $\mathrm{f}$ & si & $\mathrm{h}$ & $300-350$ & $2-12$ & $\mathrm{n}$ \\
\hline Amentotaxus & c & co & h, p & $6-10$ & $2-8$ & $\mathrm{n}$ \\
\hline Araucaria & $\mathrm{f}$ & si & $\mathrm{h}$ & $900-1500$ & $6-20$ & $\mathrm{n}$ \\
\hline Athrotaxis & $s, f$ & si & $\mathrm{h}$ & $10-61$ & $1-5$ & $\mathrm{n}, \mathrm{sc}$ \\
\hline Austrocedrus & $\mathrm{s}$ & si & $\mathrm{h}$ & $8-20$ & 3 & sc \\
\hline Austrotaxus & $\mathrm{f}$ & si & h, p & $12-18$ & $3-4$ & $\mathrm{n}$ \\
\hline Callitris & s & si & $\mathrm{h}$ & $8-20$ & $2-6$ & sc \\
\hline Calocedrus & s & si & $\mathrm{h}$ & $6-18$ & $1-6$ & sc \\
\hline Cathaya & $\mathrm{f}$ & si & $\mathrm{h}$ & $70-130$ & 2 & $\mathrm{n}$ \\
\hline Cedrus & s & si & $\mathrm{h}$ & $400-800$ & 2 & $\mathrm{n}$ \\
\hline Cephalotaxus & $\mathrm{f}$ & со & h, p & $10-15$ & $2-4$ & $\mathrm{n}$ \\
\hline Chamaecyparis & $\mathrm{s}$ & si & $\mathrm{h}$ & $8-16$ & $1-4$ & sc \\
\hline Cryptomeria & $\mathrm{f}$ & si & $\mathrm{h}$ & $15-30$ & $1-6$ & $\mathrm{n}$ \\
\hline Cunninghamia & c & si & $\mathrm{h}$ & $12-86$ & $1-4$ & $\mathrm{n}$ \\
\hline Cupressus & s & si & $\mathrm{h}$ & $8-24$ & $1-10$ & sc \\
\hline Dacrycarpus & $\mathrm{f}$ & si & $\mathrm{h}$ & $38-46$ & 2 & $\mathrm{n}$ \\
\hline Dacrydium & $\mathrm{s}$ & si & $\mathrm{h}$ & $48-105$ & 2 & sc \\
\hline Diselma & $\mathrm{s}$ & si & $\mathrm{h}$ & $6-12$ & 2 & sc \\
\hline Falcatifolium & $\mathrm{f}$ & si & $\mathrm{h}$ & $50-70$ & 2 & $\mathrm{n}$ \\
\hline Fitzroya & $\mathrm{f}$ & si & $\mathrm{h}$ & $15-24$ & $2-7$ & $\mathrm{n}$ \\
\hline Glyptostrobus & s & si & $\mathrm{h}$ & $14-20$ & $2-9$ & sc \\
\hline Halocarpus & $\mathrm{s}$ & si & $\mathrm{h}$ & $18-28$ & 2 & $\mathrm{sc}, \mathrm{n}$ \\
\hline Juniperus & $\mathrm{s}, \mathrm{f}, \mathrm{c}$ & si & $\mathrm{h}$ & $6-28$ & $1-8$ & $\mathrm{sc}, \mathrm{n}$ \\
\hline Keteleeria & c & si & $\mathrm{h}$ & $80-122$ & 2 & $\mathrm{n}$ \\
\hline Lagarostrobus & s & si & $\mathrm{h}$ & $10-20$ & 2 & sc \\
\hline Larix & s & si & $\mathrm{h}$ & $40-70$ & 2 & $\mathrm{n}$ \\
\hline Lepidothamnus & s & si & $\mathrm{h}$ & $15-22$ & 2 & sc \\
\hline Libocedrus & s & si & $\mathrm{h}$ & $6-24$ & $3-6$ & sc \\
\hline Manoao & s & si & $\mathrm{h}$ & $6-12$ & 2 & sc \\
\hline Metasequoia & $\mathrm{f}$ & si & $\mathrm{h}$ & $15-39$ & $1-4$ & $\mathrm{n}$ \\
\hline Microbiota & $\mathrm{s}$ & si & $\mathrm{h}$ & $10-12$ & $1-3$ & sc \\
\hline Microcachrys & s & si & $\mathrm{h}$ & $20-30$ & 2 & sc \\
\hline Nageia & c & co & $\mathrm{h}$ & $55-75$ & 2 & $\mathrm{n}$ \\
\hline Neocallitropsis & s & si & $\mathrm{h}$ & $24-32$ & $2-14$ & $\mathrm{n}$ \\
\hline Nothotsuga & $\mathrm{f}$ & si & $\mathrm{h}$ & $6-14$ & 2 & $\mathrm{n}$ \\
\hline Papuacedrus & s & si & $\mathrm{h}$ & $8-30$ & $2-6$ & sc \\
\hline Parasitaxus & s & si & $\mathrm{h}$ & $8-13$ & 2 & sc \\
\hline Pheroshaera & s & si & $\mathrm{h}$ & $6-15$ & 2 & sc \\
\hline Phyllocladus & $\mathrm{f}$ & si & $\mathrm{h}$ & $30-40$ & 2 & $\mathrm{n}$ \\
\hline Picea & $\mathrm{f}$ & si & $\mathrm{h}$ & $160-190$ & 2 & $\mathrm{n}$ \\
\hline Pilgerodendron & $\mathrm{s}$ & si & h & $12-20$ & $4-10$ & $\mathrm{n}$ \\
\hline Pinus & $\mathrm{f}$ & si & $\mathrm{h}$ & $50-210$ & 2 & $\mathrm{n}$ \\
\hline Platycladus & s & si & $\mathrm{h}$ & $6-16$ & $1-6$ & sc \\
\hline Podocarpus & c & со & $\mathrm{h}$ & $108-284$ & 2 & $\mathrm{n}$ \\
\hline Prumnopitys & $\mathrm{f}$ & co & $\mathrm{h}$ & $22-58$ & 2 & $\mathrm{n}$ \\
\hline Pseudolarix & c & si & $\mathrm{h}$ & $30-40$ & 2 & $\mathrm{n}$ \\
\hline Pseudotaxus & $\mathrm{f}$ & co & $\mathrm{p}$ & $6-12$ & $3-8$ & $\mathrm{n}$ \\
\hline Pseudotsuga & $\mathrm{f}$ & si & $\mathrm{h}$ & $50-80$ & 2 & $\mathrm{n}$ \\
\hline Retrophyllum & c & co & $\mathrm{h}$ & $40-60$ & 2 & $\mathrm{n}$ \\
\hline Saxegothaea & $\mathrm{f}$ & si & h & $24-32$ & 2 & $\mathrm{n}$ \\
\hline
\end{tabular}




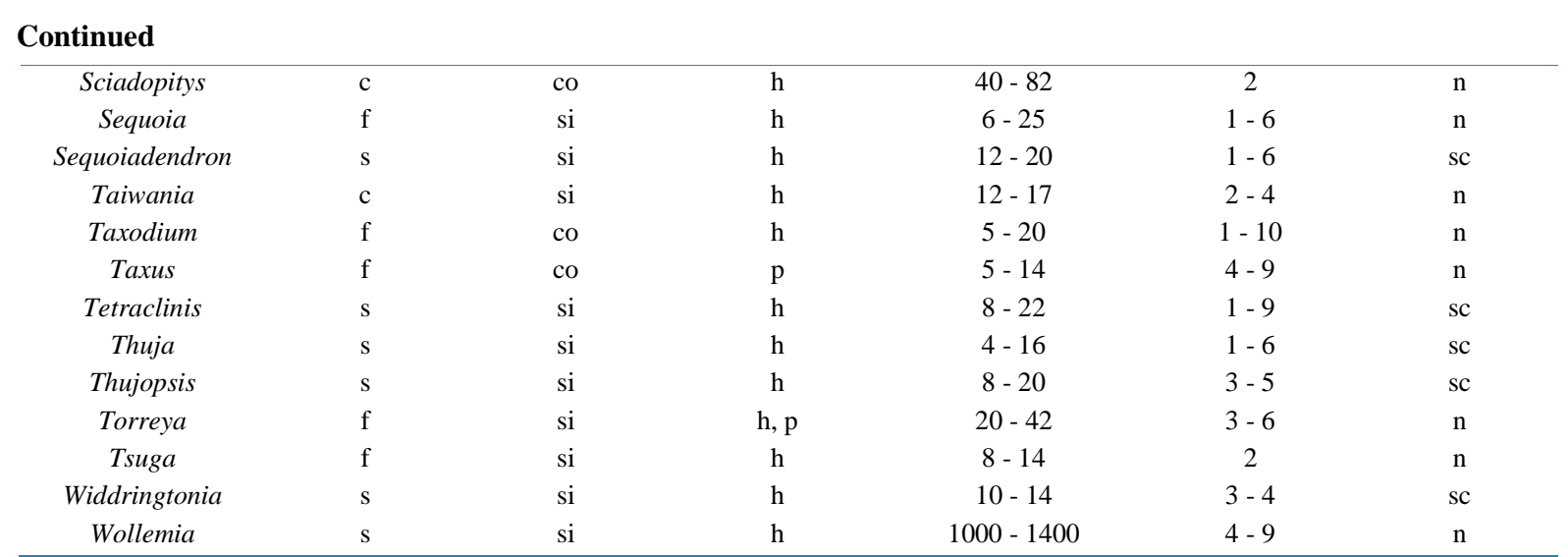

$\mathrm{f}$ = fascicular; $\mathrm{s}=$ solitary; $\mathrm{c}$ = clustered; $\mathrm{si}$ = simple; $\mathrm{co}=$ compound; $\mathrm{h}$ = hyposporangiate; $\mathrm{p}=$ perisporangiate; $\mathrm{n}=$ needle or flattened leaves or phyllocladien; sc = scale leaves; ${ }^{*}$ per sporangiophore.

leaves usually show many branchings, while taxa with needle leaves usually show conspicuously less branchings.

\subsection{Scutellum Size and Sporangiophore Type}

The size of the scutellum is larger at the base of the male cone than near the tip of the cone (compare Figure 4(a) and Figure 4(b), Figure 1(c2), Figure 1(e3)). This reduction of the scutellum size within a cone was comprehensively investigated in Juniperus chinensis (Table 2), Juniperus oxycedrus, and Chamaecyparis lawsoniana (Figure 1(c5)). The shape of the sporangiophores at the top of the male cone (Figure 4(c), Figure 4(d), Figure 4(g), Figure 4(h)) often differs from the shape of the remaining sporangiophores (Figure 4(a)). At the top of the male cone, the scutellum of the sporangiophore can be completely reduced, leaving only stalked sporangia, as in Juniperus or Callitris (Figure 4(c), Figure 4(h)). Perisporangiate and hyposporangiate sporangiophores occur in Taxaceae (Figure 3(a), Figure 3(c)). However, the male cones of Callitris rhomboidea often have a perisporangiate sporangiophore in the terminal position (Figure 4(g)). In Juniperus and Chamaecyparis, the sporangia are attached laterally to the stalk of the sporangiophore and not fused to the scutellum (Figure 4(e), Figure 4(f)).

\subsection{Number of Sporangia per Sporangiophore}

By counting the number of sporangia per sporangiophore and the number of sporangiophores of several cones and individuals of several cones from the same and different tree, we determined that species do not have a single cone type. Several different male cone configurations could be observed in one species. However, these different cone configurations can be visualized in a single cone diagram (Figure 4(i)).

The number of sporangia per sporangiophore in conifers ranges from 1 in Chamaecyparis (occasionally found) to 20 in Araucaria (occasionally found). Within Araucariaceae, the sporangiophores form two rows of sporangia (Figure 4(h)). Two sporangia per sporangiophore occur most frequently in conifers and a number of 4.6 sporangia are observed on average in conifers. In Pinaceae, Podocarpaceae, and Sciadopityaceae, the number of sporangia per sporangiophore is usually 2. In Cupressaceae, the number ranges from 1 (occasionally found) to 10 (occasionally found); however, 2 sporangia per sporangiophore is rarely observed. In Araucariaceae the number of sporangia per sporangiophore is the highest in conifers with up to 20 sporangia (Table 1, Figure 5(b)).

\subsection{Number of Sporangiophores per Male Cone}

In conifers, the number of sporangiophores per cone ranges from 4 in Thuja (occasionally found) to 1500 in Araucaria (occasionally found). Approximately 15 sporangia per sporangiophore are observed most frequently in conifers, but an average number of 65 sporangia per sporangiophore has been seen. In Cupressaceae and Taxaceae, the number of sporangiophores per cone is conspicuously low compared to the other conifer families. The number of sporangiophores per cone is the highest among the conifers in Araucariaceae (300 - 1500 sporangiophores). Sciadopityaceae show a moderate value of sporangiophores (40 - 82 per cone). In Pinaceae, the 

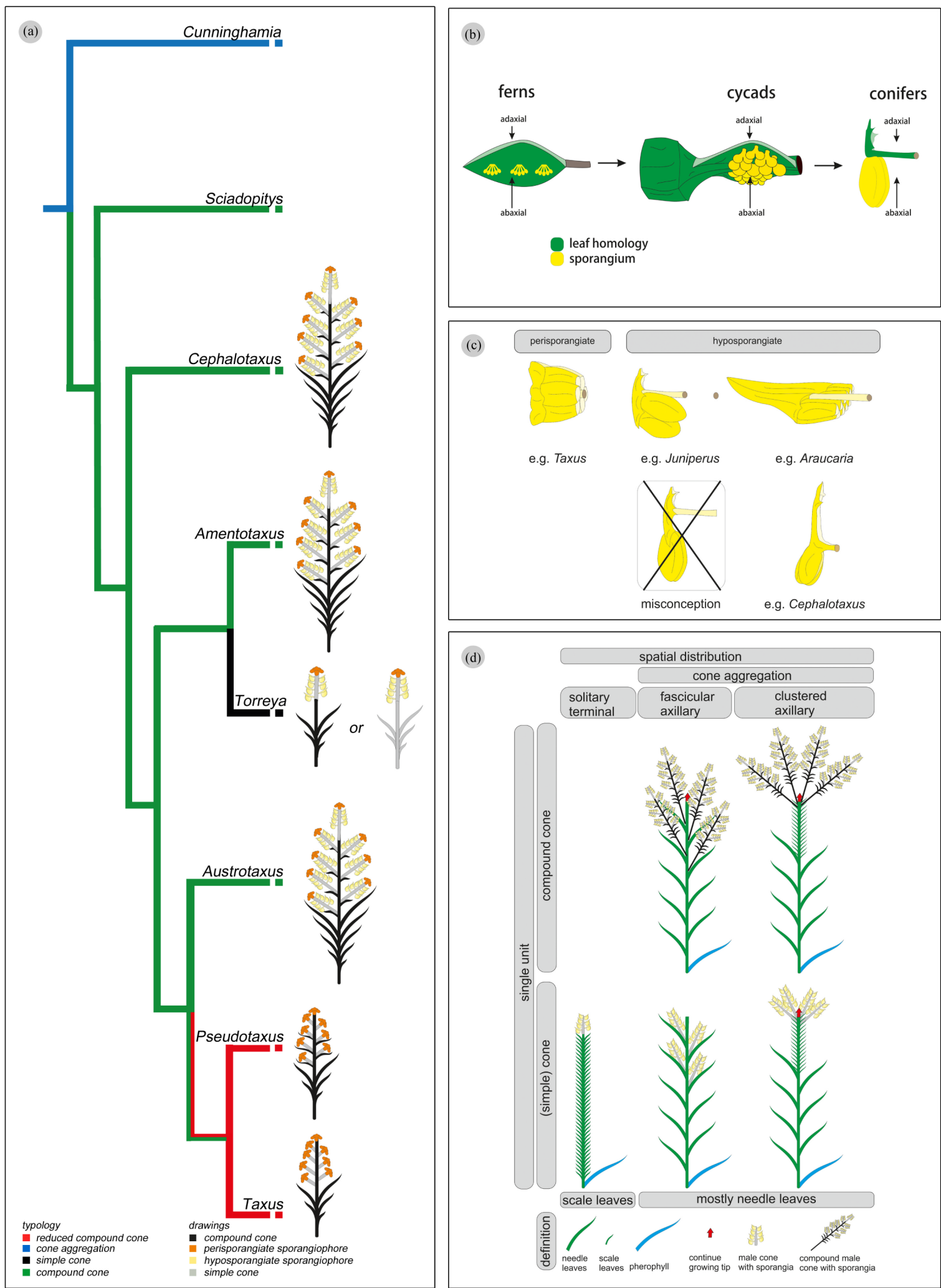

(d)



Figure 3. Character evolution. (a) Trait reconstruction of male reproductive structure evolution in Taxaceae; (b) Transition series for sporangiophore/microsporophylls in gymnosperms and ferns; (c) Transition series for sporangiophore types in conifers; (d) Different male cone types in conifers. 

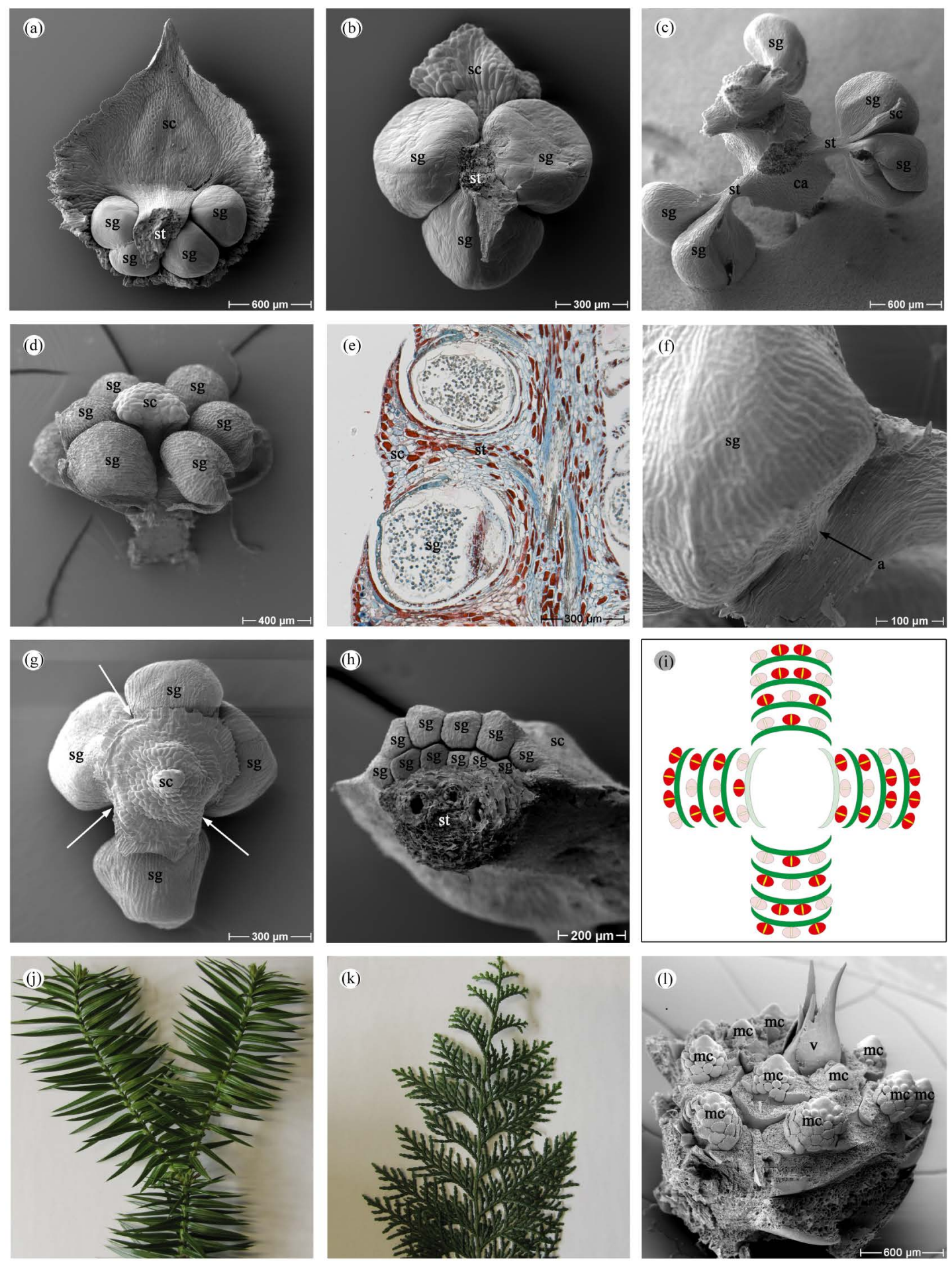

Figure 4. Vegetative and reproductive structures of conifers. (a) sporangiophore from the base of a Juniperus oxycedrus male cone; (b) sporangiophore from the top of a Juniperus oxycedrus male cone; (c) terminal sporangia of Juniperus oxycedrus; (d) top of the male cone of a Juniperus oxycedrus; (e) sporangiophore of Tetraclinis articulata; (f) sporangium with attachment point; (g) perisporangiate sporangiophor of Callitris rhomboidea; (h) sporangiophore of Araucaria; (i) cone diagram of Chamaecyparis lawsoniana; sporangiophore = green, sporangium = red, always present = dark, sometimes present = light; $(\mathrm{j})$ branchlet of Cunninghamia lanceolata; $(\mathrm{k})$ branchlet of Chamaecyparis pisifera; (l) male cone cluster with a vegetative tip. Attachment point (a), cone axis (ca), male cone (mc), scutellum (sc), sporangium (sg), stalk (st), and vegetative tip (v). 
Table 2. Scutellum width and length within a Juniperus chinensis cone.

\begin{tabular}{lcc}
\hline Position & Scutellum width & Scutellum length \\
\hline 1. Whorl (base) & $1.54 \mathrm{~mm}(100 \%)$ & $1.75(100 \%)$ \\
2. Whorl & $1.46 \mathrm{~mm}(95 \%)$ & $1.67(95 \%)$ \\
3. Whorl & $1.41 \mathrm{~mm}(92 \%)$ & $1.48(85 \%)$ \\
4. Whorl & $1.20 \mathrm{~mm}(78 \%)$ & $1.32(75 \%)$ \\
5. Whorl & $1.08 \mathrm{~mm}(70 \%)$ & $1.11(63 \%)$ \\
6. Whorl (tip) & $0.43 \mathrm{~mm} \mathrm{(28 \% )}$ & $0.73(42 \%)$ \\
\hline
\end{tabular}

number of sporangiophores per cone can be very low, as in Tsuga (8 - 14), but also rather high, as in Pinus (50 210). In Podocarpaceae, the number of sporangiophores per cone is high in the Dacrydioid and Polypodiopsis clades, but low in the remaining Podocarpaceae clade (Table 1, Figure 5(c)).

\section{Discussion}

\subsection{Leaf Type and Male Cone Distribution}

Needle leaves are primitive in conifers and in Cupressaceae (Figure 5(a)), which is reflected in the ontogeny of young plants or seedlings that initially develop needle leaves and switch only later to scale leaves. Fascicular and clustered male cones are also primitive in conifers, as well as in Cupressaceae, and probably in Podocarpaceae (Figure 5(a)).

The spatial distribution of the male cones correlates with leaf type and branching frequency. Almost all genera with needle leaves have fascicular or clustered male cones, while those with scale leaves shows solitary male cones (Figure 5(a)). The genera with scale leaves tend to have a high number of branchings, while the genera with needle leaves tend to have a low number. Genera with large needle leaves (e.g., Cunninghamia) branch only few times (Figure 4(j)). Higher branching in Cunninghamia would yield leaves that shade each other. In contrast, genera with scale leaves (e.g., Chamaecyparis) can branch many times without producing leaves which shade each other (Figure 4(k)). A high branch frequency produces many terminal tips, even if not all tip branches are involved in the continued growth of the plant. Thus as this branching strategy evolved, the taxa with scale leaves began to produce a single terminal male cone instead of multiple male cones close to each other. The wind can likely distribute the pollen of solitary male cones more efficiently than pollen of many male cones that shade each other.

Clusters of male cones often proliferate, as in Cunninghamia (Figure 1(d2)). Therefore, it is likely that the male cones are axillary and the terminal branches continue to grow. An important difference between clustered and fascicular aggregations is that clustered male cones have compressed internodes and reduced leaves in the generative part (Figure 3(d)), while fascicular male cones have normal internodes and normal leaves in the generative part. If the male reproductive structures are fascicular or clustered, the axillary structure can be either a simple male cone (analogous to a flower, e.g. Pseudolarix, Figure 2(d1)) or a compound male cone (analogous to an inflorescence, e.g. Prumnopitys, Figure 2(c5)). Furthermore, it is important to distinguish between aggregations with male cones (e.g. Cryptomeria, Figure 1(d1)) and aggregations with compound male cones (e.g. Cephalotaxus, Figure 1(c4)). A compound male cone shows limited growth, has narrowed or absent leaves (compared to normal vegetative branchlets), and is ramified. Moreover, compound cones are shed entirely after pollen shed, whereas the axis into which fascicular or clustered cones insert is persistent. Additionally, aggregations with simple male cones do not show at least one of these characters. For example, Cryptomeria has normal leaves in the generative part and the generative part continues vegetative growth. Our definition of the term compound cone (inflorescence) thus proved to be beneficial in the context of conifers, although other definitions are possible [38].

\subsection{Male Cones in Taxaceae}

Taxaceae are the most prominent group within the conifers that form compound cones. Cephalotaxus with compound cones [18] is the sister group of the remaining Taxaceae (Figure 3(a)). Therefore, the compound cone is likely to be primitive in Taxaceae. This is reflected in the results of our analysis (Figure 3(a)). Austrotaxus with compound cones [39] (Figure 1(b4)) is the sister group of Pseudotaxus, which shows reduced compound cones [12] (Figure 2(d2)) and Taxus has ostensibly simple cones, which most likely represent reduced 

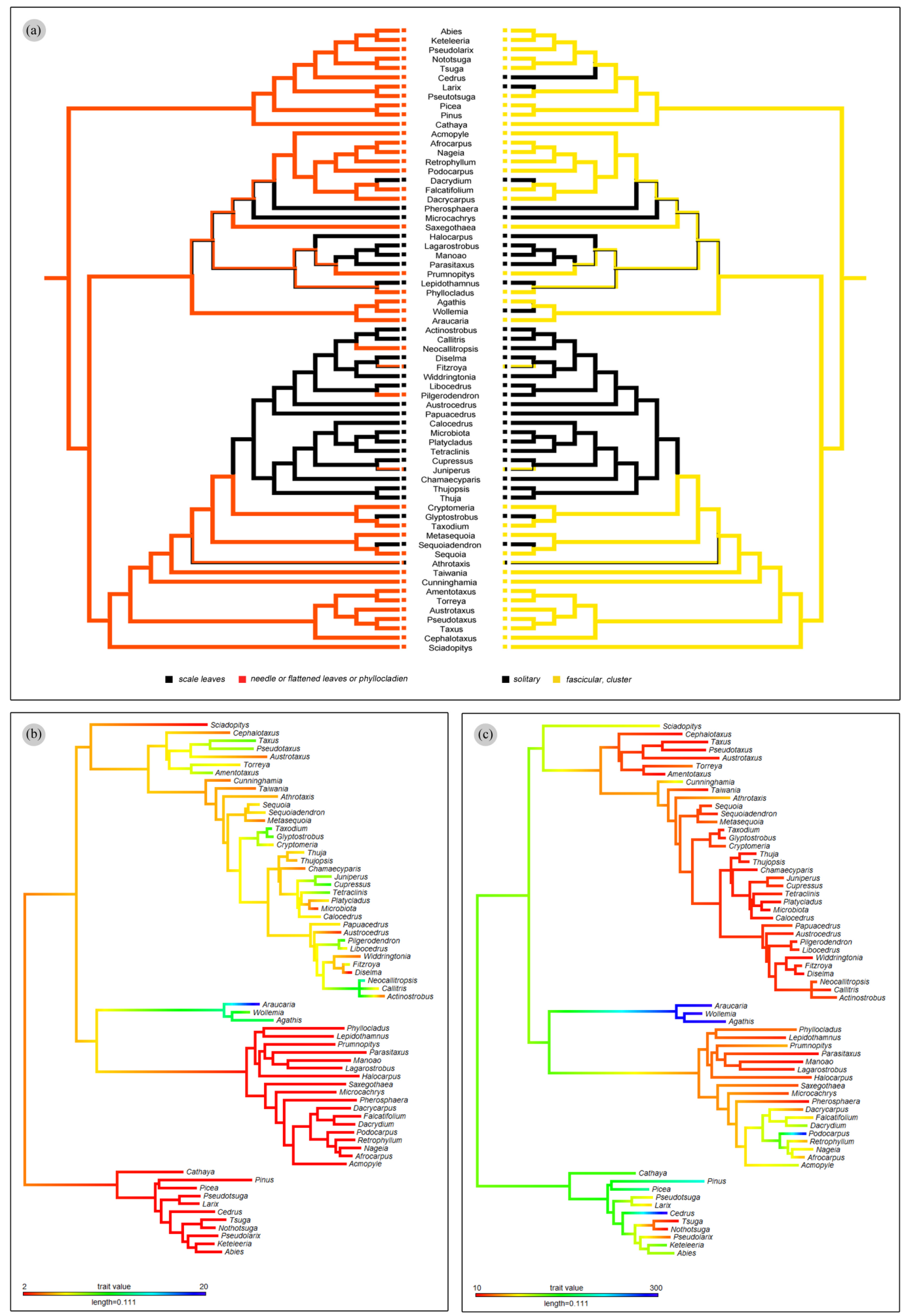

Figure 5. Trait reconstruction on genera level. The reconstruction was calculated using Mesquite (a) and contMAP in R ((b) and (c)). Character states are represented in different colors. (a) left: Leaf type. A right: spatial distribution of male cones; (b) Number of sporangia per sporangiophores; (c) Number of sporangiophores per cone. Araucaria, Wollemia, Agathis, and Cedrus unlike other genera possessed more than 300 sporangiophores per cone. These corrections were made to better present this numerical distribution. 
compound cones [18] (Figure 2(e5)). This interpretation is not only supported by their close phylogenetic relationship, but also by the presence of lateral perisporangiate sporangiophores, which occur exclusively in terminal compound cones. This can be regarded as classical transition or reduction series. Amentotaxus, which has compound cones [40], is sister of Torreya [18] (Figure 2(f3)) which has simple male cones (Figure 3(a)). Based on this, the male cones of Torreya are likely to be reduced compound cones, which possess lateral hyposporangiate sporangiophores, confirming the interpretation of Mundry and Mundry [18] and Dörken et al. [12]. By plotting the most recent phylogeny, we confirmed the transition series described by Dörken et al. [12] and extended the series to include the genera Amentotaxus and Austrotaxus.

However, trait evolution is not always a reductive process. This process could be caused by simple activation or silencing of a transcription factor or the modification of a gene promoter which could theoretically induce a change from compound cone to simple cone or vice versa. In Fitzroya for example, a branched male instead of a simple cone is frequently observed which could be induced by a simple genetic mutation.

Notably, Taxaceae are not the only taxon, which has compound cones. In Taxodium distichum (Figure 2(e4)) compound cones are observed in the same position as simple male cones in Taxodium mucronatum. In the Podocarpaceae genera, compound male cones occur in some species of Podocarpus, Prumnopitys, and Retrophyllum. Also Sciadopitys verticillata has compound male cones. Moreover, even in extinct conifers, the occasional occurrence of compound cones has been documented [41].

\subsection{Perisporangiate and Hyposporangiate Type}

Several authors consider the sporangiophores of conifers to be homologues structures [19]-[21]. Hyposporangiate sporangiophores of many conifer species are probably homologous, but there are examples of Taxaceae showing that e.g. the sporangiophore of Pseudotaxus is homologous to a male cone and not to a single sporangiophore of Cephalotaxus. This phenomenon was caused by a reduction in Taxaceae. The number of additional reductions that occurred in conifers, or at the base of the conifers, is still unclear. Therefore the question of the potential homology question of sporangiophores also remains disputable.

Most conifers have hyposporangiate sporangiophores; however, perisporangiate sporangiophores are regularly limited to Taxaceae, except for some mutants in the genus Callitris. As the Taxaceae are not a basal group of conifers (Figure 5(a)), the perisporangiate sporangiophore is likely to be a derived character state. Thus, the perisporangiate sporangiophore is derived from the hyposporangiate sporangiophore. One explanation could be that the perisporangiate sporangiophore is a kind of fusion product of several hyposporangiate sporangiophores (probably three, Figure 4(g)), which has been previously proposed in the literature [18] [42]. Thomson [42] reported that fused sporangiophores occur occasionally in every conifer family at the apex.

In conifers, the position of the sporangia at the hyposporangiate sporangiophore can vary (Figure 3(c)). The variability of the sporangia position originates from differences in the spatial and temporal growth pattern. Sporogenous tissue is formed quite early during the development of the sporangiophores [18]. At that time, the stalk and scutellum are not differentiated; therefore, the sporangia are initiated at the abaxial side of the dorsiventral primordium. Due to differences in spatial and temporal growth, the sporangia end up at different position on the sporangiophore (Figure 3(c)).

\subsection{Microsporophyll}

The term microsporophyll implies that a sporangiophore is homologous to a leaf. Some authors therefore consider the sporangiophore to be a peltate leaf with the sporangia being inserted on the margin and a radial orientation in all directions [19] (Figure 3(c)). Dluhosch [19] suggested a secondary shift of the microsporangia from the margin of the scutellum to the stalk of the scutellum in cases that do not conform to this hypothesis (e.g. Cupressaceae). As this finding renders this hypothesis less convincing, many authors [12] [18] have preferred to use the neutral term sporangiophore.

However, the crucial issue is not the homology of a sporangiophore with a leaf itself, instead it is more crucial which part of the sporangiophore is homologous to which part of the leaf. The scutellum (or phyllom-like structure) is different in shape and size in different species [19] [23] (Figure 3(c)). In many species, e.g. in Tetraclinis, the sporangium arises at the abaxial side of the stalk. In some species (e.g. Juniperus oxycedrus) the scutellum narrows from the base to the top of the male cone (compare Figure 4(a) and Figure 4(b)). At the top of the cone, the scutellum can even be completely reduced and only stalk and sporangia are left (Figure 4(c)). In 
these cases, the sporangia are always stalked. This suggests that it is not the scutellum that forms the sporangia, but the stalk.

The origin of the sporangia (the stalk) is easy to delineate in species with well-developed scutellum. If the scutellum is only developed adaxial, it is referred to as phyllom-like. Thus, if the abaxial part of the scutellum is not obstructing the direction of the growth of the sporangia, they might develop more towards the distal end. The more distal position of the sporangia is regarded as attached to the scutellum edge. We think the more distal position of the sporangia should be regarded as attached to the stalk. However, it is still difficult to define the border between the stalk and scutellum and thus to determine whether the sporangiophore as well as scutellum is homologous in all conifers (Figure 3(c)).

However, the stalk, at least, in some conifers might be homologous to a leaf, supporting the sporophyll concept in a novel way. This would also conform to Cycas sporangiophores, which show a more plane stalk (Figure 3(b)). However, the cycad sporophyll differs from those of the conifers, as they exhibit a pinnate arrangement and soral cluster of sporangia [43]. This feature is very similar to the reproductive leaves of higher ferns. The stalk of at least some conifers could be homologous to the sporophyll of ferns and cycads, all of which form sporangia on the abaxial side (Figure $3(b)$ ).

Male cones and male sporangiophores in conifers are thus much more variable than assumed in the past. However, ontogenies of male cones of most conifer families are still lacking. Furthermore, it might be fruitful to re-investigate the fossil conifers and their relative with focus on male cones.

\subsection{Amount of Pollen}

There are numerous parameters (the number of male cones on the tree, the number of sporangiophores per cone, the number of sporangia per sporangiophore, and the number of pollen per sporangium) which affect the amount of pollen, and thus determine the ability to produce an appropriate amount of pollen for successful pollination. Theoretically speaking, if all parameters were low, probably too little pollen would be produced for successful pollination. However, if all parameters were high, it is probable that too much energy would be wasted. Indeed, both scenarios would have a negative impact on the fitness; therefore, a balanced adjustment of these parameters is probably a key factor for a successful pollen dispersal strategy.

Within the conifers, there are some examples that clearly reflect this balancing act. For example, Pinaceae, Podocarpaceae, and Sciadopitys usually produce only 2 sporangia per sporangiophore, while the number of sporangiophores per cone often is very high. In contrast, Cupressaceae and Taxaceae produce a higher number of sporangia per sporangiophore, while the number of sporangiophores is rather low. Araucariaceae (Figure 1(a5), Figure 1(b1), Figure 2(f5)) produce many sporangia per sporangiophore and many sporangiophores (Figure 5(b), Figure 5(c)), but the number of cones per tree is very low. The current trait reconstruction methods estimate a low number of sporangia per sporangiophore (about 5) in conifers at their origin (Figure 5(b)). However, 2 sporangia per sporangiophore as is observed in the Pinaceae (the most basal group) could also conceivably be character that existed at the origin of conifers. Furthermore, the number of sporangiophores per cone was estimated as relatively high (about 150) for the base of the conifers (Figure 5(c)).

\section{Acknowledgements}

The paper was written in memory of Markus Naumann, who made these fantastic SEM images. The authors would like to thank the staff of all botanical gardens, herbaria (Ruhr-Universität Bochum, Royal Botanic Gardens, Nationaal Herbarium Nederland, Leiden University branch, New York Botanical Garden, Muséum National d'Histoire Naturelle), and other botanical institutions, as well as all the private collections, that provided access to collections, material, and their generous help in support of the present study.

\section{References}

[1] Leslie, A.B., Beaulieu, J.M., Rai, H.S., Crane, P.R., Donoghue, M.J. and Mathews, S. (2012) Hemisphere-Scale Differences in Conifer Evolutionary Dynamics. Proceedings of the National Academy of Sciences of the United States of America, 109, 16217-16221. http://dx.doi.org/10.1073/pnas.1213621109

[2] Little, D.P. (2006) Evolution and Circumscription of the True Cypresses (Cupressaceae: Cupressus). Systematic Botany, 31, 461-480. http://dx.doi.org/10.1043/05-33.1 
[3] Farjon, A. (2010) A Handbook of the World's Conifers. Volume I, II, Brill, Leiden, Boston.

[4] Knopf, P., Schulz, C., Little, D.P., Stützel, T. and Stevenson, D.W. (2012) Relationships within Podocarpaceae based on DNA Sequence, Anatomical, Morphological, and Biogeographical Data. Cladistics, 28, 271-299. http://dx.doi.org/10.1111/j.1096-0031.2011.00381.X

[5] Mao, K.S., Milne, R.I., Zhang, L.B., Peng, Y.L., Liu, J.Q., Thomas, P., Mill, R.R. and Renner, S.S. (2012) Distribution of Living Cupressaceae Reflects the Breakup of Pangea. Proceedings of the National Academy of Sciences of the United States of America, 109, 7793-7798. http://dx.doi.org/10.1073/pnas.1114319109

[6] Little, D.P., Knopf, P. and Schulz, C. (2013) DNA Barcode Identification of Podocarpaceae-The Second Largest Conifer Family. PLOS ONE, 8, 1-11. http://dx.doi.org/10.1371/journal.pone.0081008

[7] Rothwell, G.W. and Basinger, J.F. (1979) Metasequoiamilleri n.-sp., Anatomically Preserved Pollen Cones from the Middle Eocene (Allenby Formation) of Columbia. Canadian Journal of Botany-Revue Canadienne De Botanique, 57, 958-970. http://dx.doi.org/10.1139/b79-118\#.U4w8iShCCLc

[8] Serbet, R. and Stockey, R.A. (1991) Taxodiaceous Pollen Cones from the Upper Cretaceous (Horseshoe Canyon Formation) of Drumheller, Alberta, Canada. Review of Palaeobotany and Palynology, 70, 67-76. http://dx.doi.org/10.1016/0034-6667(91)90078-H

[9] Smith, S.Y. and Stockey, R.A. (2002) Permineralized Pine Cones from the Cretaceous of Vancouver Island, British Columbia. International Journal of Plant Sciences, 163, 185-196. http://dx.doi.org/10.1086/324553

[10] Chamberlain, C.J. (1935) Gymnosperms: Structure and Evolution (Reprint 1982). University of Chicago Press, Chicago.

[11] Schulz, C. and Stützel, T. (2006) Variability of Pollen Cones in Chamaecyparis as an Example for Cupressaceae Pollen Cones. Feddes Repertorium, 117, 146-157. http://dx.doi.org/10.1002/fedr.200511085

[12] Dörken, V.M., Zhang, Z.X., Mundry, I.B. and Stützel, T. (2011) Morphology and Anatomy of Male Cones of Pseudotaxus chienii (W.C. Cheng) W.C. Cheng (Taxaceae). Flora, 206, 444-450.http://dx.doi.org/10.1016/j.flora.2010.08.006

[13] Schulz, C., Jagel, A. and Stützel, T. (2003) Cone Morphology in Juniperus in the Light of Cone Evolution in Cupressaceae s.l. Flora, 198, 161-177. http://dx.doi.org/10.1078/0367-2530-00088

[14] Schulz, C. and Stützel, T. (2007) Evolution of Taxodiaceous Cupressaceae (Coniferopsida). Organisms Diversity \& Evolution, 7, 124-135. http://dx.doi.org/10.1016/j.ode.2006.03.001

[15] Dörken, V.M. and Stützel, T. (2012) Proliferating Seed Cones in Metasequoia glyptostroboides Hu \& Cheng (Cupressaceae s.l., Coniferales) Elucidating the Evolution of Seed Cones and Ovules in Cupressaceae s.l. and Maybe Conifers on the Whole. Feddes Repertorium, 122, 409-420. http://dx.doi.org/10.1002/fedr.201200004

[16] Mohl, H.V. (1845) IV. Über die Männlichen Blüthen der Coniferen. Vermischte Schriften Botanischen Inhalts, Tübingen, 45-61.

[17] Parlatore, F. (1868) Coniferae. In: de Candolle, A.P., Ed., Prodromus Systematis Regni Vegetabilis, Vol. 16, No. 2, G. Masson, Paris, 361-521.

[18] Mundry, I.B. and Mundry, M. (2001) Male Cones in Taxaceae s.l.-An Example of Wettstein's Pseudanthium Concept. Plant Biology, 3, 405-416. http://dx.doi.org/10.1055/s-2001-16466

[19] Duluhosch, H. (1937) Entwicklungsgeschichtliche Untersuchung über die Mikrosporophylle der Koniferen. Bibliotheca Botanica, 114, 1-24.

[20] Dupler, A.W. (1919) Staminate Strobilus of Taxus canadensis. Botanical Gazette, 68, 345-366. http://www.jstor.org/stable/10.2307/2469243 http://dx.doi.org/10.1086/332570

[21] Worsdell, W.C. (1901) The Morphology of the "Flower” of Cephalotaxus. Annals of Botany, 15, 637-652. http://aob.oxfordjournals.org/content/os-15/4/637

[22] Celakovsky, L. (1879) Zur Gymnospermie der Coniferen. Flora, 62, 257-264, 273-283.

[23] Goebel, K. (1923) Organographie der Pflanzen. Gustav Fischer, Jena.

[24] Pryer, K.M., Schneider, H., Smith, A.R., Cranfill, R., Wolf, P.G., Hunt, J.S. and Sipes, S.D. (2001) Horsetails and Ferns Are a Monophyletic Group and the Closest Living Relatives to Seed Plants. Nature, 409, 618-622. http://dx.doi.org/10.1038/35054555

[25] Malaspina, T.T., Cecchi, L., Morabito, M., Onorari, M., Domeneghetti, M.P. and Orlandini, S. (2007) Influence of Meterological Conditions on Male Flowers Phenology of Cupressus sempervirens and Correlation with Pollen Production in Florence. Trees, 21, 507-514. http://dx.doi.org/10.1007/s00468-007-0143-1

[26] Schulz, C., Knopf, P. and Stützel, T. (2005) Identification Key to the Cypress Family (Cupressaceae). Feddes Repertorium, 116, 96-146. 
[27] Gerlach, D. (1984) Botanische Mikrotomtechnik, Eine Einführung, 2. Auflage, Thieme, Stuttgart.

[28] Gerstberger, P. and Leins, P. (1978) Rasterelektronenmikroskopische Untersuchungen an Blütenknospen von Physalis philadelphia (Solanaceae). Berichte der Deutschen Botanischen Gesellschaft, 91, 381-387.

[29] Hall, T. (2004) BioEdit. Ibis Therapeutics, Carlsbad. http://mbio.ncsu.edu/BioEdit.html

[30] Vaidya, G., Lohman, D.J. and Meier, R. (2011) SequenceMatrix: Concatenation Software for the Fast Assembly of Multi-Gene Datasets with Character Set and Codon Information. Cladistics, 27, 171-180. http://dx.doi.org/10.1111/j.1096-0031.2010.00329.x

[31] Edgar, R.C. (2004) MUSCLE: Multiple Sequence Alignment with High Accuracy and High Throughput. Nucleic Acids Research, 32, 1792-1797. http://dx.doi.org/10.1093/nar/gkh340

[32] Nylander, J.A.A. (2004) MrModeltest Version 2. Program Distributed by the Author. Evolutionary Biology Centre, Uppsala University, Uppsala.

[33] Ronquist, F. and Huelsenbeck, J.P. (2003) MrBayes 3: Bayesian Phylogenetic Inference under Mixed Models. Bioinformatics, 19, 1572-1574. http://dx.doi.org/10.1093/bioinformatics/btg180

[34] Maddison, W.P. and Maddison, D.R. (2011) Mesquite: A Modular System for Evolutionary Analysis. Version 2.75. http://mesquiteproject.org

[35] Paradis, E., Claude, J. and Strimmer, K. (2004) APE: Analyses of Phylogenetics and Evolution in R Language. Bioinformatics, 20, 289-290. http://dx.doi.org/10.1093/bioinformatics/btg412

[36] Revell, L.J. (2012) Phytools: An R Package for Phylogenetic Comparative Biology (and Other Things). Methods in Ecology and Evolution, 3, 217-223. http://dx.doi.org/10.1111/j.2041-210X.2011.00169.X

[37] RStudio (2012) RStudio: Integrated Development Environment for R (Version 0.96.122) [Computer Software], Boston. http://www.rstudio.com

[38] Bateman, R.M., Hilton, J. and Rudall, P.J. (2011) Spatial Separation and Developmental Divergence of Male and Female Reproductive Units in Gymnosperms, and Their Relevance to the Origin of the Angiosperm Flower. In: Wanntorp, L. and Ronse De Craene, L.P., Eds., Flowers on the Tree of Life, Cambridge University Press, Cambridge, 8-48. http://dx.doi.org/10.1017/CBO9781139013321.002

[39] Wilde, M.H. (1975) New Interpretation of Microsporangiate Cones in Cephalotaxaceae and Taxaceae. Phytomorphology, 25, 434-450.

[40] Keng, H. (1969) Aspects of Morphology of Amentotaxus formosana with a Note on Taxonomic Position of the Genus. Journal of the Arnold Arboretum, 50, 432-448.

[41] Hernandez-Castillo, G.R., Rothwell, G.W. and Mapes, G. (2001) Compound Pollen Cone in a Paleozoic Conifer. American Journal of Botany, 88, 1139-1142. http://www.amjbot.org/content/88/6/1139 http://dx.doi.org/10.2307/2657097

[42] Thomson, R.B. (1940) The Structure of the Cone in the Coniferae. Botanical Review, 6, 73-84. http://dx.doi.org/10.1007/BF02879314

[43] Mundry, I.B. and Stützel, T. (2003) Morphogenesis of Male Sporangiophores of Zamia amblyphyllidia D.W. Stev. Plant Biology, 5, 297-310. http://dx.doi.org/10.1055/s-2003-40791 
Scientific Research Publishing (SCIRP) is one of the largest Open Access journal publishers. It is currently publishing more than 200 open access, online, peer-reviewed journals covering a wide range of academic disciplines. SCIRP serves the worldwide academic communities and contributes to the progress and application of science with its publication.

Other selected journals from SCIRP are listed as below. Submit your manuscript to us via either submit@scirp.org or Online Submission Portal.
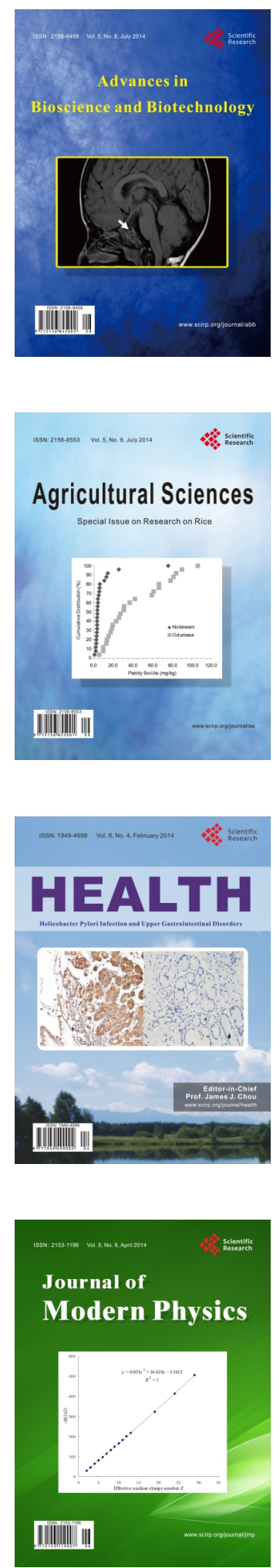
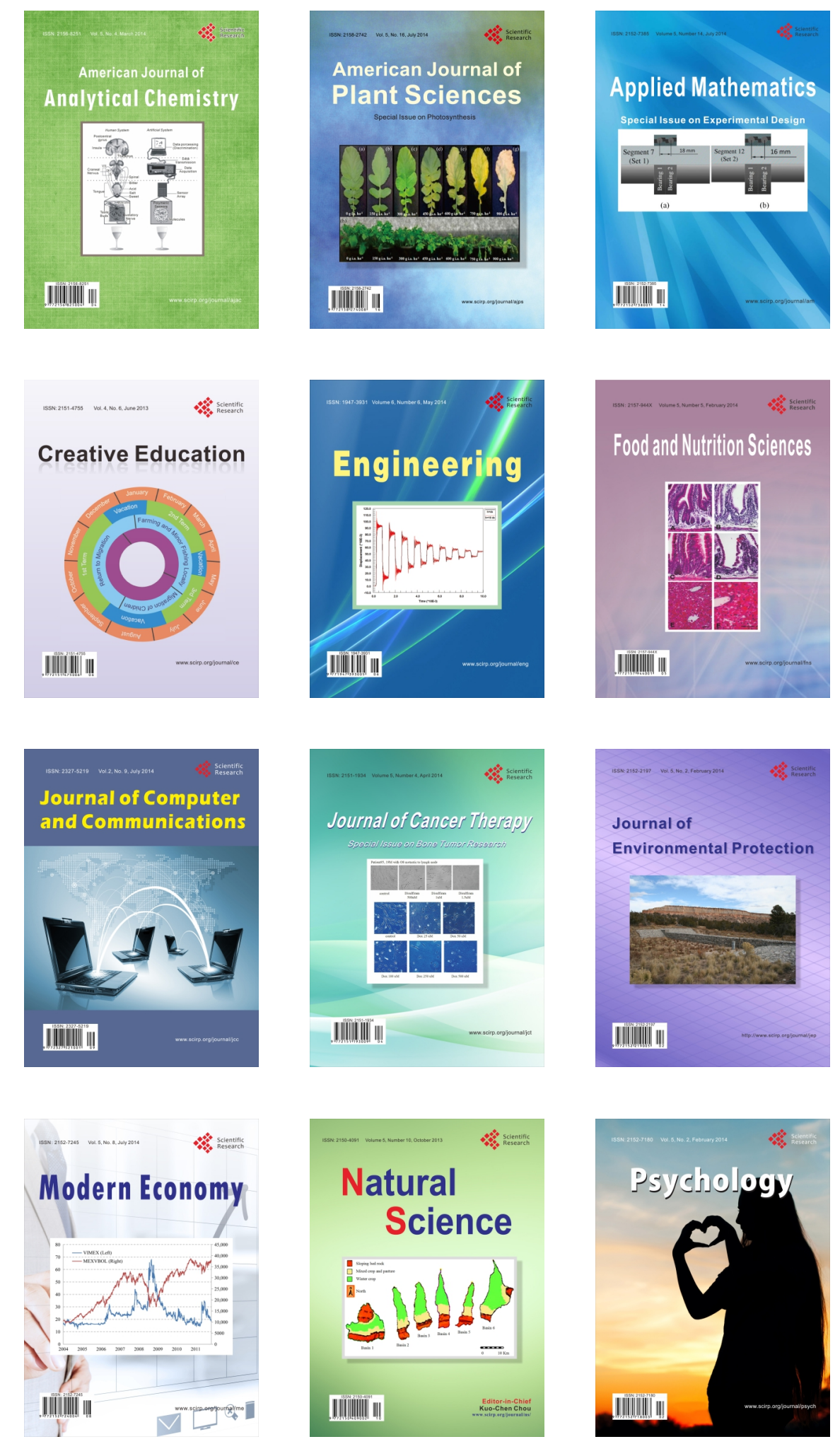